San Jose State University

SJSU ScholarWorks

Master's Theses

Master's Theses and Graduate Research

1989

\title{
The Ban on IQ testing of black children and its effect on special education placement
}

Adrienne Golden-Stone

San Jose State University

Follow this and additional works at: https://scholarworks.sjsu.edu/etd_theses

\section{Recommended Citation}

Golden-Stone, Adrienne, "The Ban on IQ testing of black children and its effect on special education placement" (1989). Master's Theses. 3071.

DOI: https://doi.org/10.31979/etd.57g2-exeg

https://scholarworks.sjsu.edu/etd_theses/3071

This Thesis is brought to you for free and open access by the Master's Theses and Graduate Research at SJSU ScholarWorks. It has been accepted for inclusion in Master's Theses by an authorized administrator of SJSU ScholarWorks. For more information, please contact scholarworks@sjsu.edu. 


\section{INFORMATION TO USERS}

The mosi advanced technology has been used to photograph and reproduce this manuscript from the microfilm master. UMI films the text directly from the original or copy submitted. Thus, some thesis and dissertation copies are in typewriter face, while others may be from any type of computer printer.

The quality of this reproduction is dependent upon the quality of the copy submitted. Broken or indistinct print, colored or poor quality illustrations and photographs, print bleedthrough, substandard margins, and improper alignment can adversely affect reproduction.

In the unlikely event that the author did not send UMI a complete manuscript and there are missing pages, these will be noted. Also, if unauthorized copyright material had to be removed, a note will indicate the deletion.

Oversize materials (e.g., maps, drawings, charts) are reproduced by sectioning the original, beginning at the upper left-hand corner and continuing from left to right in equal sections with small overlaps. Each original is also phuiugraphed in one exposure and is inclucied in reduced form at the back of the book. These are also available as one exposure on a standard $35 \mathrm{~mm}$ slide or as a $17^{\prime \prime} \times 23^{\prime \prime}$ black and white photographic print for an additional charge.

Photographs included in the original manuscript have been reproduced xerographically in this copy. Higher quality $6^{\prime \prime} \times 9^{\prime \prime}$ black and white photographic prints are available for any photographs or illustrations appearing in this copy for an additional charge. Contact UMI directly to order.

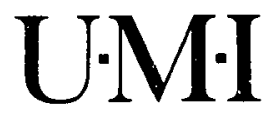

University Microfilms International

A Bell \& Howell information Company

300 North Zeeb Road, Ann Arbor, MI 48106-1346 USA

313/761-4700 800/521-0600 

Order Number 1397805

The ban on IQ testing of Black children and its effect on special education placement

Golden-Stone, Adrienne, M.A.

San Jose State University, 1989

Copyright $\mathfrak{C} 1990$ by Golden-Stone, Adrienne. All rights reserved.

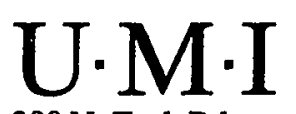

300 N. Zeeb Rd.

Ann Arbor, MI 48106 

THE BAN ON IQ TESTING OF BLACK CHILDREN AND ITS EFFECT ON SPECIAL EDUCATION PLACEMENT

\author{
A Thesis \\ Presented to \\ The Faculty of the Division of Special Education \\ and Rehabilitative Services \\ San Jose State University
}

In Partial Fulfillment

of the Requirements for the Degree

Master of Arts

by

Adrienne Golden-Stone

May, 1989 
APPROVED FOR THE DIVISION OF SPECIAL EDUCATION AND REHABILITATIVE SERVICES

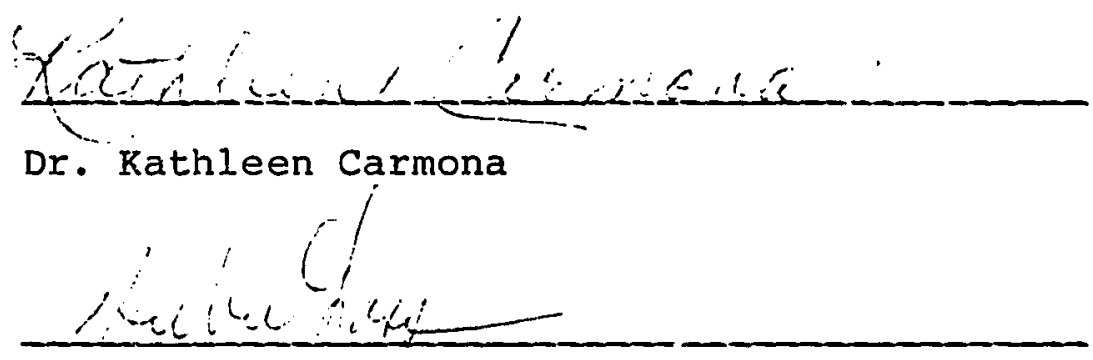

Dr. Herbert Grossman

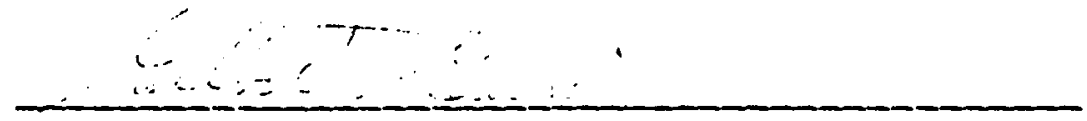

Dr. Gilbert Guerin

APPROVED FOR THE UNIVERSITY

In. Lou Lavandronle. 
ABSTRACT

THE BAN ON IQ TESTING OF BLACK CHILDREN AND ITS EFFECT ON SPECIAL EDUCATION PLACEMENT

by Adrienne Golden-Stone

Based on the Larry P. V. Riles (1979) court decision by Judge Peckham, the use of intelligence tests for Black children has been banned in California public schools. A survey of 114 school psychologists from three Bay Area school districts was conducted to investigate whether or not the use of alternative instruments to identify Black children for special education placement was effective. The psychologists indicated that alternative assessment had an adverse effect on the identification of Black children for special education. The psychologists also provided the names of alternative assessments and their frequency of use. 


\section{ACKNOWLEDGEMENT}

I wouid iike to express my appreciation and sincere thank you to my husband, Robert stone, for his support, encouragement and patience.

Gratitude is also extended to my committee members, Dr. Kathleen Carmona, Dr. Herbert Grossman, and Dr. Gilbert Guerin, for providing their valuable knowledge, assistance, and time in the initiation and completion of this theses. 
TABLE OF CONTENTS

PAGE

LIST OF TABLES ......................... vii CHAPTER

I

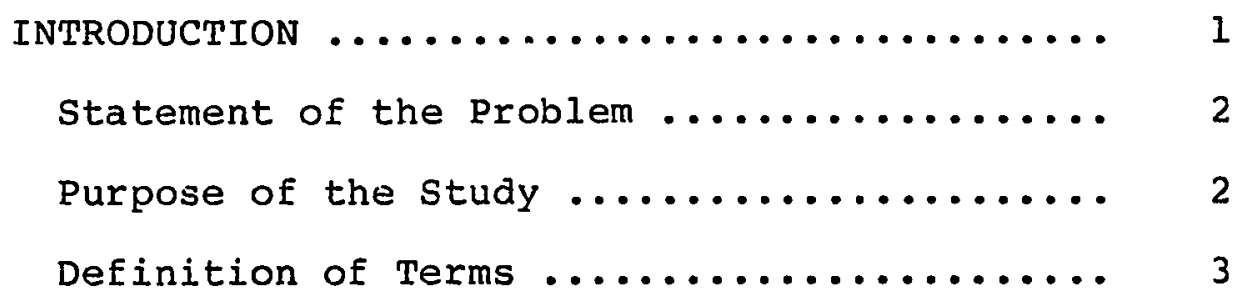

II REVIEW OF THE LITERATURE $\ldots \ldots \ldots \ldots \ldots \ldots \ldots \ldots$

Court Cases and Legislation ............ 's

Larry P. v. Wilson Riles .............. 8

School Psychologist's Perspective ........ 11

The Search for Alternative Assessment ..... 12

Alternative Assessment Techniques ........ 16

Other Placement Bias Litigation ......... 18

II METHODOLOGY $\ldots \ldots \ldots \ldots \ldots \ldots \ldots \ldots \ldots \ldots \ldots \ldots \ldots$

Purpose of the study ................. 21

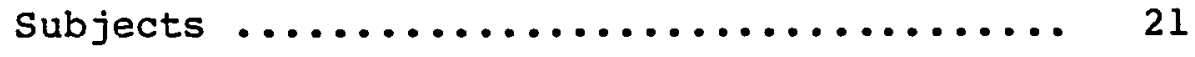

Procedure $\ldots \ldots \ldots \ldots \ldots \ldots \ldots \ldots \ldots \ldots \ldots \ldots \ldots . \ldots . \ldots . \ldots$

IV RESULTS AND DISCUSSION ................. 24

Results ........................... 24

Discussion $\ldots \ldots \ldots \ldots \ldots \ldots \ldots \ldots \ldots \ldots \ldots \ldots$

Suggestions for Future Research ......... 41

v SUMMARY $\ldots \ldots \ldots \ldots \ldots \ldots \ldots \ldots \ldots \ldots \ldots \ldots \ldots \ldots . \ldots \ldots$

Implications for the Future ........... 44 
TABLE OF CONTENTS (Continued)

PAGE

REFERENCES ............................. 46

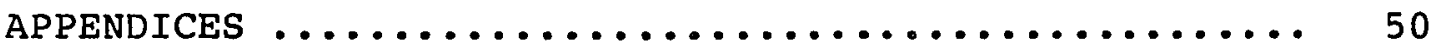

Appendix A. Cover Letter and Survey ...... 51

Appendix B. List of Tests ............ 59 
TABLE

1. Demography of subjects ................... 25

2. Percentages and Scale Ratings on the Identification Process ................... 27

3. Percentages and scale Ratings on the Assessment Instruments .................... 29

4. Percentages of Test Use and Frequency for School Achievement ................... 31

5. Percentages of Test IJse and Frequency for Intellectual Performance .............. 32

6. Percentages of Test Use and Frequency for Adaptive Behavior ................... 33

7. Percentages of Test Use and Frequency for Specific Learning Abilities and Strategies ... 34

8. Percentages of Test Use and Frequency for Classroom Behavior .................. 35

9. Percentages of Test Use and Frequency for Non-standardized Measures .............. 37

10. List of "Other" Responses .................. 38

11. List of "Other" Methods and Materials Used to Assess Black Children .............. 39 


\section{CHAPTER I}

\section{INTRODUCTION}

Seventeen years ago, the Larry P. V. Wilson Riles U.S. District Court (1971) case addressed the overrepresentation of Black students in classes for the mentally retarded through the use of standardized tests of intelligence. Presently, Black children are overrepresented in special education programs not only in California but all across the nation. Blacks comprise 168 of the student population nationally; however, they comprise 388 of the special education population. In California, Blacks make up 98 of the student population and $25 \%$ of the special education enrollment (Dent, 1986).

It was not until Judge Peckham's decision in 1979 and reaffirmation of the decision in 1986 that the use of inteiligence (IQ) tests to diagnose Black children for special education became a violation of the equal protection clause of the United States Constitution (Lambert, 1981). California has now banned the use of IQ tests for diagnosing Black students for special education purposes. Since intelligence tests have been found to be invalid assessment tools for Black children, alternative means of assessment need to be identified. However, finding the right assessment tool to diagnose Black children has put California in a state of flux. Parents, teachers, and psychologists are concerned that Black students cannot be 
fairly assessed for special education without using intelligence tests. Statement of the Problem

The specific problem is how to qualify Black children for special education placement without using IQ tests. It woul.d appear that there should be no conflict with Judge Peckham's decision because it is in accordance with The Education for All Handicapped Children Act (PL 94-142). Under PL 94-142, a student cannot be placed or identified for special services solely on the basis of IQ scores. The testing clause protects students by building in the use of non-biased assessment and multidimensional evaluation. If the IQ test is culturally biased, it cannot appropriately identify Black children for special education services. However, it appears that psychologists are having a difficult time assessing Black children for special education. Judge Peckham's decision to ban IQ tests is controversial. The literature review addresses this complex problem.

Purpose of the study

The purpose of this study was to collect data about the types of assessment being used to identify selected Black students for special education in Alameda, San Francisco, and Santa Clara counties and to investigate whether or not psychologists considered these methods appropriate. The information obtained was analyzed to answer the following 
questions:

1. Are the alternative assessment instruments adequate in diagnosing Black children for special education?

2. What types of standardized tests are being used to diagnose Black children for special education?

3. Of the standardized tests being used for assessment, which are most frequently used?

4. What types of alternative assessment are being used by school psychologists to diagnose Black children for special education?

Definition of Terms

Listed below are some terms used in this study and their definitions:

Alternative Assessment. The assessment of a student's eligibility for special education services through means other than IQ tests.

Educable Mentally Retarded (EMR). The child who deviates from the average or normal child (1) in mental characteristics, (2) in sensory abilities, (3) in neuromuscular or physical characteristics, (4) in social or emotional behavior, (5) in communication abilities, or (6) in multiple handicaps to such an extent that he requires a modification of school practices, or special education services, in order to develop to his maximum capacity. (Baca \& Cervantes, 1984, p. 42) 
Intelligence Quotient (IQ). "The results from intelligence tests which predict performance in school and reflect the degree to which children have mastered middle class cultural symbols and values" (Taylor, 1989, p. 189).

Public Law 94-142. The Education for All Handicapped Children Act guarantees a free and appropriate education to all handicapped individuals between the ages of three and twenty-one.

Special Education. The individually planned and systematically monitored arrangement of physical settings, special equipment and materials, teaching procedures, and other interventions designed to help exceptional children achieve the greatest possible self-sufficiency and academic success. (Lewis \& Doorlag, 1983, p. 10)

Test Bias. "Individuals with certain characteristics (for example, different ethnic groups, geographic regions, economic levels, sex) consistently score differently when a test is administered under similar conditions" (Taylor, 1989, p. 86 ).

Overrepresentation. A disproportionate number of minorities, compared to the regular population, placed in special education. 
CHAPTER II

REVIEW OF THE LITERATURE

Court Cases and Legislation Preceding Larry P. Case

A disportionate number of minority children have been placed in special education classes as a result of biased assessment and inappropriate placement decisions. Litigation and legislation have brought this matter to the attention of students, parents, and teachers. Several court cases were prominent in the movement toward the appropriate identification and assessment of special education students: Brown v. Board of Education (1954); Hobson v. Hansen (1967); Diana v. California Board of Education (i970); and Lau v. Nichols $(1974)$.

The landmark case in school desegregation was Brown v. Board of Education of Topeka (1954). At the conclusion of this case, it was decided that separation of students on the basis of race, separate but equal, was not acceptable. Programs which were segregated along racial lines had to be integrated to achieve racial balance.

Hobson v. Hansen (1967) was the first judicial chailenge to testing procedures and special class placement. The fundamental issue was the constitutionality of a tracking system that placed students in groups on the basis of their performance on standardized tests. The groups were classified into several levels or tracks ranging from retarded to gifted. The defendants argued that tracking 
represented an educationally sound effort to address and remediace the academic difficulties experienced by all children in the district. However, the tracking system resulted in a disproportionate number of Black children being placed in the mildly retarded track. The court struck down the tracking system, as well as the procedures used to test students for track assignment. The court ruled the system to be in violation of the equal protection clause of the United States Constitution (Prasse \& Reschly, 1986). The Diana v. California Board of Education (1970) case challenged EMR placement based on the use of English-normed intelligence tests for Spanish-speaking children. The court ruled in favor of the plaintiffs. The settlement called for the retesting of every minority, language handicapped child in his/her primary language, utilizing tests that assess performance, and the development of culturally relevant intelligence tests normed on spanish-speaking children. The Lau v. Nichols (1974) case was a class action suit brought before the United States Supreme Court in behalf of 1,800 Chinese students. The court ruled:

There was no equality of treatment merely by providing students with the same facilities, textbooks, teachers, and curriculum, for students who do not understand English are effectively foreclosed from any meaningful education. (Baca \& Cervantes, 1984, p. 68) 
Chinese students were being denied meaningful instruction in their primary language. The court ruled that every student has a right to a free and appropriate education. The court's decision relied on Title VI of the Civil Rights Act of 1964, which bans discrimination based on the grounds of race, color, or national origin in any program or activity receiving federal financial assistance.

In addition to Title VI of the Civil Rights Act of 1964, which guarantees the rights of minorities, legislation also guarantees the rights of handicapped children. The laws having the greatest effect on minimizing biased assessment and placement practices are the Education for All Handicapped Children Act (Public Law 94-142) and Section 504 of the Vocational Rehabilitation Act of 1973.

The Education for All Handicapped Children Act (Public Law 94-142) has five key elements:

1. The provision of free, appropriate public education for all handicapped children.

2. Procedures for testing and evaluation of children that are non-discriminatory in terms of race and culture. Children must be tested in their native or home language.

3. The development of an Individualized Educational Program (IEP) for each handicapped child. 4. Education in the least restrictive environment, meaning the education of handicapped children with 
nonhandicapped children to the greatest extent possible.

5. The assurance of due process procedures for the child and his or her parent or guardian. (Lewis \& Doorlag, 1983, p. 9)

Section 504 of the Vocational Rehabilitation Act of 1973 guarantees rights to handicapped persons of all ages. Known as the civil rights act for the handicapped, it provides freedom from discrimination and the guarantee of benefits from federally funded programs or activities. Provisions of the law are as follows:

1. Employers are required to provide equal

recruitment, employment compensation, job assignments, and fringe benefits for the handicapped.

2. All new public facilities are required to be accessible to the handicapped.

3. Handicapped children of school age are entitled to a free and apprepriate public education. 4. Discrimination in admission to institutions of higher education is prohibited.

5. Discrimination is forbidden in providing health, welfare, and other social service programs. (Lewis \& Doorlag, 1983, p. 9)

Larry P. V. Wilson Riles (1971)

of all the literature and legislation discussed, none 
has had a greater impact on the assessment and placement of Black children than Larry P. V. Wilson Riles (1971). A group of Black parents from San Francisco claimed their children had been inappropriately classified and placed in classes for the Educable Mentally Retarded (EMR); furthermore, they charged that this placement procedure violated the Civil Rights Act of 1964 and the right to equal protection guaranteed by both the California Constitution and the Fourteenth Amendment to the United States Constitution. In June, 1972, the federal district court granted a preliminary injunction against the use of IQ tests. for EMR class placement. The case was appealed, and the Court of Appeals for the Ninth Circuit upheld the injunction and expanded it to include all California Black children who had been or would be wrongly placed or maintained in EMR programs. After seven years of trial proceedings, Federal District Court Judge Robert F. Peckham ordered the elimination of the disproportionate enrollment of Blacks in EMR classrooms and a permanent injunction on the use of standardized intelligence tests for EMR class placement of Blacks. The proceedings revealed the following points which led to the judge's decision:

(1) The evidence did not show that the fifteen-point lower mean IQ test score of Blacks was the result of genetic inferiority or could be completely explained by lower socioeconomic status; therefore, the lower 
scores must also reflect racial bias in the tests themselves; (2) the evidence did not validate that the biased scores identified only those Blacks who could not profit from regular or remedial instruction and who met the California definition of EMR; (3) intelligence quotients were central to California's EMR placement process; (4) since the scores were both biased against Blacks and central to placement, they contributed significantly to the disproportionate enrollment of Blacks in EMR classes; and (5) the disproportionate enrollment had an impermissibly discriminatory effect on misclassified Blacks, since EMR placement was 'essentially permanent' and 'educationally dead-end, isolating and stigmatizing'. (Rose \& Huefner, 1984, p. 5)

Furthermore, on September 26, 1986, Judge Peckham ruled the following, which exceeded his previous decision: "All California public schools are barred from administering Intelligence Quotient (IQ) tests to Black students for any special education reason" (Staff, 1986, p. 1). The resulting directive, sent to all California public schools, mandated the following:

There are no special education related purposes for which IQ tests shall be administered to Black pupils. The following reasons are not permissible 
justification for the administration of an IQ test to a Black pupil:

1.) As part of a comprehensive educational plan to which a parent has consented;

2.) To gain diagnostic information;

3.) To develop goals and objectives;

4.) To determine special education pupil's educational needs;

5.) To develop a pupil's strengths and weaknesses elicited by the IQ test. Further, IQ tests have been determined to be invalid in assessing Black pupils for specific learning disabilities. The prohibition of IQ testing applies even though pupils are no longer placed in special day classes designed for educable mentally retarded (EMR) students. A review of the districts' use of IQ tests in compliance with this directive shall be part of the coordinated Compliance Monitoring Review Process. (Staff, 1986, p. 1).

School Psychologist's Perspective

As a result of Judge Peckham's decision, psychologists were faced with the new problem of how to qualify Black children for special education placement without using IQ tests. The decision was not favorably received by all psychologists. Some members of the California Association of School Psychologists (CASP) reacted angrily: 
Are we going to take this lying down? Where does a judge come off mandating how social science skills will be applied by a profession. Can we reopen the case - . take the judge to task? What are test publishers doing to defend the tests?" (Porter, 1987, p. I).

However, some CASP members reacted positively. Winget (1988a) addressed CASP's opinion that Judge Peckham's decision:

will help chilaren become more successful in their learning environments because school psychologists will more fully utilize skills in psychological and learning theory, observation, and consultation with an increased emphasis on learning needs and specific interventions. (p. 4)

$\cdot$

King presented a positive view of the impact of the decision on psychologists:

We no longer respond to the fact Judge Peckham took away IQ tests. In a way this event has given us an opportunity to take back ourselves and show that a test is not a psychologist. The test is only as good as the psychologist interpreting it. (Winget, $1988 \mathrm{a}$, p. 9)

The Search for Alternative Assessment

In search of solutions to alternative assessment, the California state Department of Education and CASP have 
developed their own task force. In March of 1987, Patrick Campbell, Director of the Division of Special Education, established the Larry P. Task Force, a 45-member team, which consisted of teachers, psychologists, speech and language specialists, nurses, special and general education administrators, parents, and other related members. The purpose of this advisory group was to develop and recommend guidelines and policy revisions to school districts in relation to alternative assessment. The task force was divided into two committees: assessment and policy.

The assessment committee was responsible for developing guidelines which addressed alternative assessment areas. Roy Logan, the chairperson of this committee, reported that its goal was "to produce a document that will provide guidelines and set parameters for conducting an assessment of ability for, not only Black pupils, but for any pupil" (Ramage, Logan, \& Thomas, 1988, p. 2). The document by the committee will include a historical perspective, purpose and philosophy, the target audience, and basic terms. Also, it will address support and interventions within general education, present positive assessment practices with emphasis on the multidisciplinary process, and describe several assessment models.

The policy committee was chaired by Barbara Thomas. Its responsibility was to compare federal and state policies with the Larry $P$. case, making reinterpretations and 
recommending policy revisions as needed. More specifically, the policy recommendations will focus on standardized tests, the Learning Disabled (LD) discrepancy formula, the definition of intelligence, records that include IQ scores, and other related issues. As of January 8, 1988, the advisory group for the Larry P. Task Force had made the following policy recommendations:

1. Districts are urged to notify parents of Black pupils receiving special education services that pupil records are being purged of all references to I.Q. data (score, or method to compute score). The notification, in writing, should advise the parents of their rights to copies of the data and include a timeline allowing the parents a period of time in which to request copies.

2. Under no circumstances should I.Q. scores or I.Q. references be made available to IEP teams making pupil placement decisions. (Campbell, 1988, p. 1)

The Larry P. Task Force report was completed in June of 1988. The report, which has not yet been circulated, includes the previously announced policy revision recommendations and new alternative assessment guidelines. Also, recommendations for research, training, and other areas of interest will be included in the report (Ramage, 1988). 
The CASP task force was also divided into two committees, assessment and advisory, addressing issues from the Larry P. decision. The Assessment Committee, chaired by Modesto City School psychologist, Ed King, has studied various assessment alternatives to the IQ test. The results will be reported to the CASP membership detailing the best practices available. Thus far, the committee has recommended six models of alternative assessment: curriculum-based assessment, learning potential assessment, cognitive behavior modification, information processing, Piagetian model, and eco-systems.

The advisory committee chaired by CASP President, Ken Porter, held brainstorming sessions to sort out the various issues raised by the decision. The purpose of this committee was to facilitate decision making by the CASP Board.

In addition to the task force, the state Department's Division of Special Education contracted the services of Dr. Harola Dent, a renowned Black psychologist and expert witness for the plaintiffs in the Larry P. case, to conduct a project to pilot and evaluate alternative assessment models. Dent, frustrated that Black children have not benefited from the banning of IQ tests, predicts that: Not only Black kids will benefit from the current activities of the Department, but kids from other groups--not just minorities but white kids also-- 
because we'll obtain more information with

alternative assessments. People will see that you can get appropriate information about how children learn and what to do when they're not learning effectively. (winget, 1988b, p. 1)

Dent's project will evaluate the effectiveness of non-biased assessment models and the appropriateness of placement for Black children. The project aims to develop strategies "to help the child move on the educational continuum" (Winget, $1988 \mathrm{~b}$, p. 10).

\section{Alternative Assessment Techniques}

While the school psychologists wait for the results of the efforts of the two task forces to prescribe alternative forms of assessment, many authors in the field have developed other strategies and techniques to screen Black students for special education services. Olion and Gillis-olion (1984) maintained that the following principles should be inherent in a good assessment program for Black students :

1) Assessment is more than testing. It is a multifaceted process of collecting data to document the performance of students in their environs so that educational decisions can be made . . 2) Assessment is not the first step. . . The class-room teacher should be required to document that the regular curriculum and at least three 
alternative instructional strategies have been tried and evaluated.

3) Black parents must be actively involved...

4) Teachers must be actively involved . .

5) Assessment must be multifactored. [Data should come from a variety of sources.] . . .

6) Assessment must occur early. [If learning difficulties are detected early, they are easier to remediate.] . .

7) Assessors must be culturally aware [to assure proper assessment of students with cultural differences ] . .

8) Assessment must ascertain strengths and weaknesses. [Focusing on the strengths makes learning successful.] . .

9) Assessment must be ongoing. As students progress, many of the initial recommendations must be modified or eliminated, based on the needs of the individual students. (Olion \& Gillis-Olion, 1984, p. 26)

Olion and Gillis-olion indicated that these nine principles maximize the information gained from criterion-referenced testing, psychosocial testing, observation, and informal inventories.

Lopez (1988) offered the following criteria for assessing alternatives to IQ tests to determine a student's 
eligibility for special education:

1. Do the assessment procedures yield information about a student's eligibility for special education according to the existing regulations or other recognized diagnostic criteria?

2. Have the procedures been shown to be appropriate for Black students?

3. Are they reliable and valid?

4. Do they provide educationally relevant information?

5. Do they assist in making consistent decisions about students' eligibility for special education? 6. Do any of the supporting data for the proceeding [sic] questions appear in refereed-professional journals or references? (p. 22)

\section{Other Placement Bias Litigation}

Regardless of the strides made by the State Department of Education and the California Association of School Psychologists to reform assessment, the battle for the use of IQ tests continues to be an issue in California, as well as other states. Three cases in particular are: (1) Parents in Action in Special Education (PASE) $v$. Hannon (1980); (2) Marshall V. Georgia (1984); and (3) Crawford V. Honig, filed in May of 1988. The PASE v. Hannon (1980) case was similar to Larry P. v. Riles (1971) because it was triggered by the 
disproportionate number of Black children who were enrolled in EMR classes in Illinois; however, a controversial decision was delivered. Federal District Court Judge Grady ruled that IQ tests were not biased and that the extensive procedural protections, including the requirement of multifactored assessment, guarded against misplacement of minority students as mildly retarded. Hence, the decision established the existence of a legal basis for continued use of IQ tests despite effects of overrepresentation (Prasse \& Reschly, 1986).

Another landmark decision in a federal district court, Marshall v. Georgia (1984), ruled that overrepresentation of Black students in special class programs for the mildly retarded did not constitute discrimination. The issue of IQ testing, however, was not addressed in this case.

Crawford V. Honig. filed in May, 1988 (Sattler, 1988), involved a group of families with school-aged children who joined together to fight the state's ban on intelligence tests for Black students. They cited superintendent william Honig for allegedly violating the civil and constitutional rights of Black families. The Complaint for Declaratory Judgment and Injunctive Relief filed in the Crawford case asserted four counts of violations of the federal and state civil rights protections:

1. Under the first count, the complaint alleges that the State Defendants violated 42 U.S.C. 1983 of 
the Civil Rights Act of 1964.

2. The second count was brought pursuant to Title VI of the Civil Rights Act of 1964.

3. The third count was brought pursuant to the Education of the Handicapped Act, Pub. L. 94-142. 4. The fourth count was brought pursuant to Ariticle 1, 7 of the California Constitution and state statute. (Sattler, 1988, p. 20)

As of December, 1988, the outcome of Crawford v. Honig (1988) had yet to be resolved. The Larry P. (1971) decision may be reviewed by the U.S. Supreme Court in the event defendants like Crawford continue to appeal the California appellate court verdict. 
CHAPTER III

METHODOLOGY

Purpose of the Study

This study investigated the types of assessment being used by school psychologists to identify selected Black students for special education in Alameda, San Francisco, and Santa Clara counties. These psychologists were also asked for their opinions as to the appropriateness of these methods.

\section{Subjects}

The target population surveyed consisted of 219 school psychologists employed in Alameda, San Francisco, and Santa Clara counties. These psychologists from the California Public School Directory (1987) were selected because they were responsible for assessing elementary through high school level students for special education services. Procedure

The items on the questionnaire (see Appendix A) were developed from information obtained from two main sources: informal interviews and a review of literature. Three psychologists were informally interviewed about their areas of concern regarding Judge Peckham's decision, and how they were currently identifying and assessing Black children for special education services.

A review of the literature revealed a similar study conducted in 1983 by Ruben Gentry. His study identified, 
by means of a questionnaire, the feelings and opinions of intern special education teachers concerning the educational problems and needs of the minority handicapped child. Futuristic perspectives, sociocultural factors, instructional process, and identification and evaluation procedures were examined. The identification and evaluation section of Gentry's questionnaire included factors related to the identification process, assessment instruments, examiners/techniques, and placement criteria. The style and format of the questionnaire developed by this researcher were based on Gentry's identification and evaluation section.

The list of tests that were included in the questionnaire were taken from those provided in the index in Assessing Special Students (McLoughlin \& Lewis, 1986). This list included formal and informal tests and tests that measure school achievement, intellectual performance, adaptive behavior, learning abilities and strategies, classroom behavior, and non-standardized tests.

Each school psychologist received a four-part questionnaire (see Appendix A). Part One of the questionnaire sought demographic information. Part Two asked for opinions on the use and need of assessment instruments to identify Black children for special education. Part four presented a list of standardized and non-standardized tests used to assess children for special 
education. The psychologists were requested to indicate which tests they used for Black children and how frequently they used them.

Each section of the questionnaire provided descriptive data. Part one revealed the type and level of school setting, kind of special education population served, and number of years served in the psychologists' current position. Part Two described the adequacy of services for Black children in terms of identification and placement. Part Three detailed information related to the assessment of Black children for special education and whether or not the instruments used were inandated, adequate, or required special training. Part Four ranked each standardized test instrument according to frequency of use. 
CHAPTER IV

RESULTS AND DISCUSSION

This study collected data about the types of assessment used to identify selected Black students for special education and examined psychologists' feelings about the appropriateness of the identification and assessment process without the use of IQ tests. The information obtained was analyzed to answer the following questions:

1. Are the alternative assessment instruments adequate in diagnosing Black children for special education?

2. What types of standardized tests are being used to diagnose Black children for special education?

3. Of the standardized tests being used for assessment, which are most frequently used?

4. What types of alternative assessment are being used by school psychologists to diagnose Black children for special education?

Results

To obtain this information, a total of 219 questionnaires were mailed to selected school psychologists employed in Alameda, San Francisco, and Santa Clara counties; 114 questionnaires were returned and analyzed. Demographic information obtained on Part one of the questionnaire appears in Table 1.

The 114 subjects were employed by the schools as psychologists $(948)$ and intern psychologists $(48)$. In 
Table 1

Part One: Demography of subjects

$\mathrm{N}=114$

Institution: Infant only

Preschool only

$0 \%$

Elementary only

$35 \%$

Secondary only

288

Preschool and Elementary

118

Preschool and $\mathrm{K}-12$

All levels

Public

748

Private

18

Both Public and Private

Unknown

Population

Served:

Learning Handicapped

548

Special Day Class

37 웅

Resource Specialist Program

368

Educable Mentally Retarded

318

Severely Emotionally Disturbed

248

Severely Handicapped

78

Unknown

48

(table continues) 
$\begin{array}{llr}\text { Position: } & \text { School Psychologist } & 948 \\ & \text { Psychologist Intern } & 48 \\ & \text { Unknown } & 28\end{array}$

Years in Position: $M=10.4(S D=6.5)$

Completed Survey on This Issue Within 5 Years: 58

Expressed Interest in Survey Results: 718

addition, the majority of the psychologists served the learning handicapped (548) through the public education system (748). The average school psychologist indicated a period of 10.4 years in his/her current position.

To ascertain their opinions the psychologists were asked to rate key statements about the identification process and assessment instruments on Part Two of the questionnaire. The responses to the statements about the identification process are shown in Table 2 .

There were three statements in Part Two of the questionnaire. Out of 114 psychologists responding to the first statement, $77 \%$ indicated that the diagnosis of Black children using means other than IQ testing is inadequate. The vast majority of psychologists feel they cannot adequately assess Black children for special education without the use of an IQ instrument. Only 198 believe they can adequately assess Black children under their current 
Table 2

Part Two: Percentages and Scale Ratings on

the Identification Process

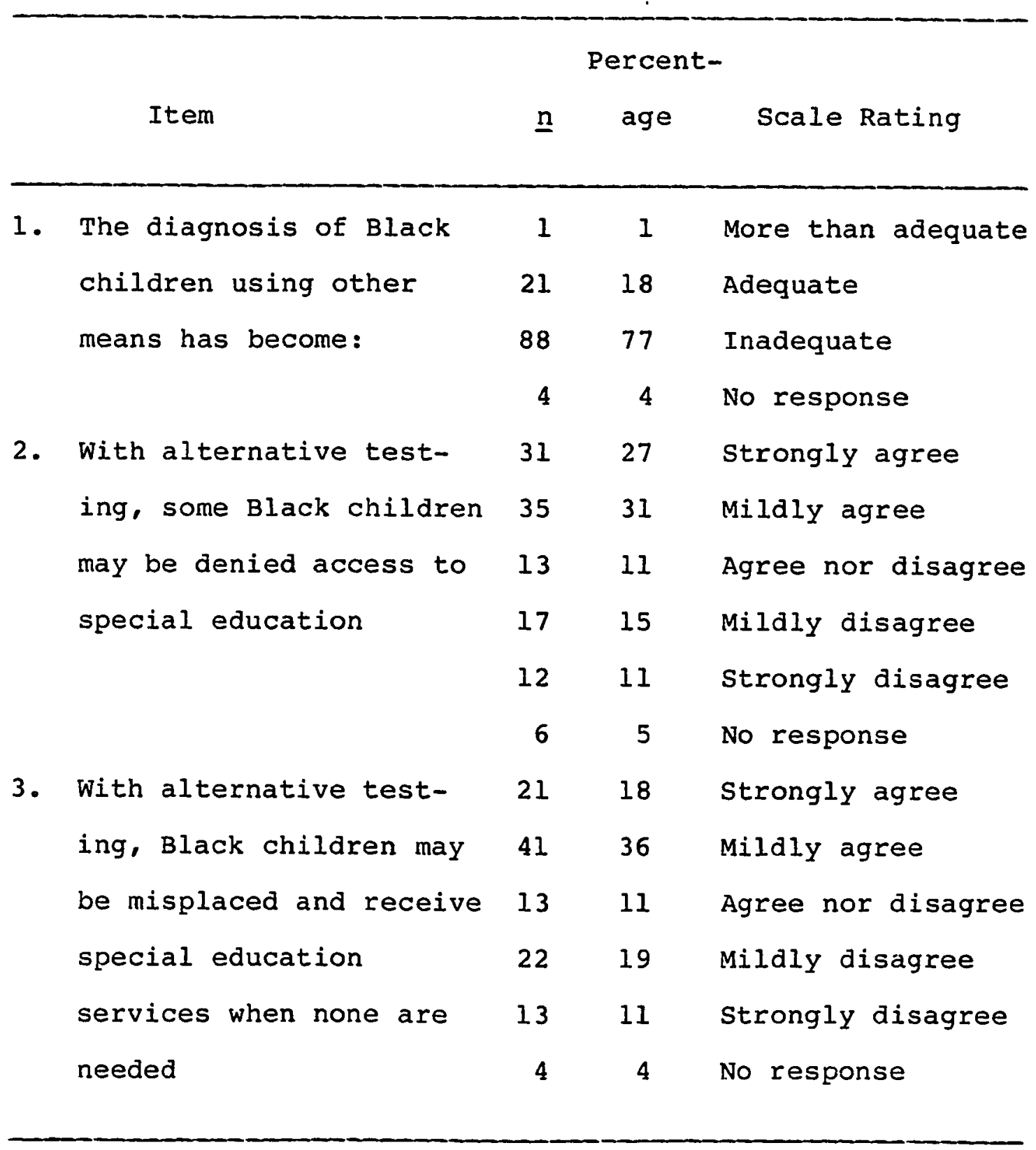

Note. Items are written on the survey instrument. $\underline{n}=$ number of respondents out of 114 . 
means. In response to the second statement, $58 \%$ of the psychologists agree and 268 of the psychologists disagree that, as a result of the use of alternative testing, some Black children may be denied access to special education. The final statement in this section implied that the use of alternative testing of Black children might be responsible for their misplacement and unnecessary receipt of special education services when none are needed. The combined totals of the response scores indicate that 548 of the respondents agree and $30 \%$ disagree with this statement.

The response choices in Part Three of the questionnaire were as follows: "often," "sometimes," or "never" (Appendix A, question 4); and "yes" or "no" (Appendix A, questions 5 and 6). Table 3 represents the psychologists' opinions about the adequacy of assessment of Black students (see Appendix A for survey questions in their complete form). Part Three of the questionnaire also included three statements. Out of 114 subjects responding to Question 4, 688 of the subjects indicated that their district does not mandate which tests they must use to identify students for special education services. Although some psychologists commented that their districts offered suggested lists of alternative assessment tests (see Appendix B), they were allowed to choose which ones to use, if any at all. On the fifth question, 758 of the subjects indicated that the alternative forms of assessment which were currently being 
Table 3

Part Three: Percentages and Scale Ratings on

the Assessment Instruments

\begin{tabular}{lccc}
\multicolumn{1}{c}{ Item } & \multicolumn{3}{c}{ Percent- } \\
& age & Scale Rating \\
\hline 4. Your district mandates & 16 & 14 & Often \\
which tests must be & 19 & 17 & Sometimes \\
used to assess Black & 77 & 68 & Never \\
students for special & 2 & 2 & No response \\
Education & & & \\
Current tests available & 25 & 22 & Yes \\
are adequate for the & 86 & 75 & No \\
assessment of Black & 3 & 3 & No response \\
children & & &
\end{tabular}

Note. Items are written on the survey instrument. $\underline{\mathrm{n}}=$ number of respondents out of 114 .

used to assess Black children were not adequate. The final question in this section inquired about the need for 
additional or specialized training to assess Black children for special education. The responses to this question indicated that $58 \%$ of the subjects felt psychologists need additional or specialized training. A majority of psychologists do not feel thoroughly prepared to test Black students.

Tables 4 through 11 present the rank order of the tests included in Part Four of the questionnaire. The ranking begins with the most frequently used test and ends with the least frequently used test. Tests are grouped in each of the following categories: school achievement, intellectual performance, adaptive behavior, specific learning abilities and strategies, classroom behavior, nonstandardized tests, and other tests. For each test, a percentage score is provided in three scoring categories: $\mathrm{N}=$ never, $\mathrm{S}=$ sometimes, $0=$ often. Also, a fourth column indicates the number of responses to each test item listed. In Table 4 , the three achievement tests most frequently used by school psychologists are the Wide Range Achievement Test (95\%), the Woodcock-Johnson Psycho-Educational Battery (848), and the Peabody Individual Achievement Test ( $81 \%$ ).

Eight test instruments are included in Table 5. The results show that, in the area of intellectual performance, the three most frequently used tests are the WoodcockJohnson Psycho-Educational Battery (238), the Learning Potential Assessment Device (228), and the system of 
Table 4

Part Four: Percentages of Test Use and Freguency for School Achievement

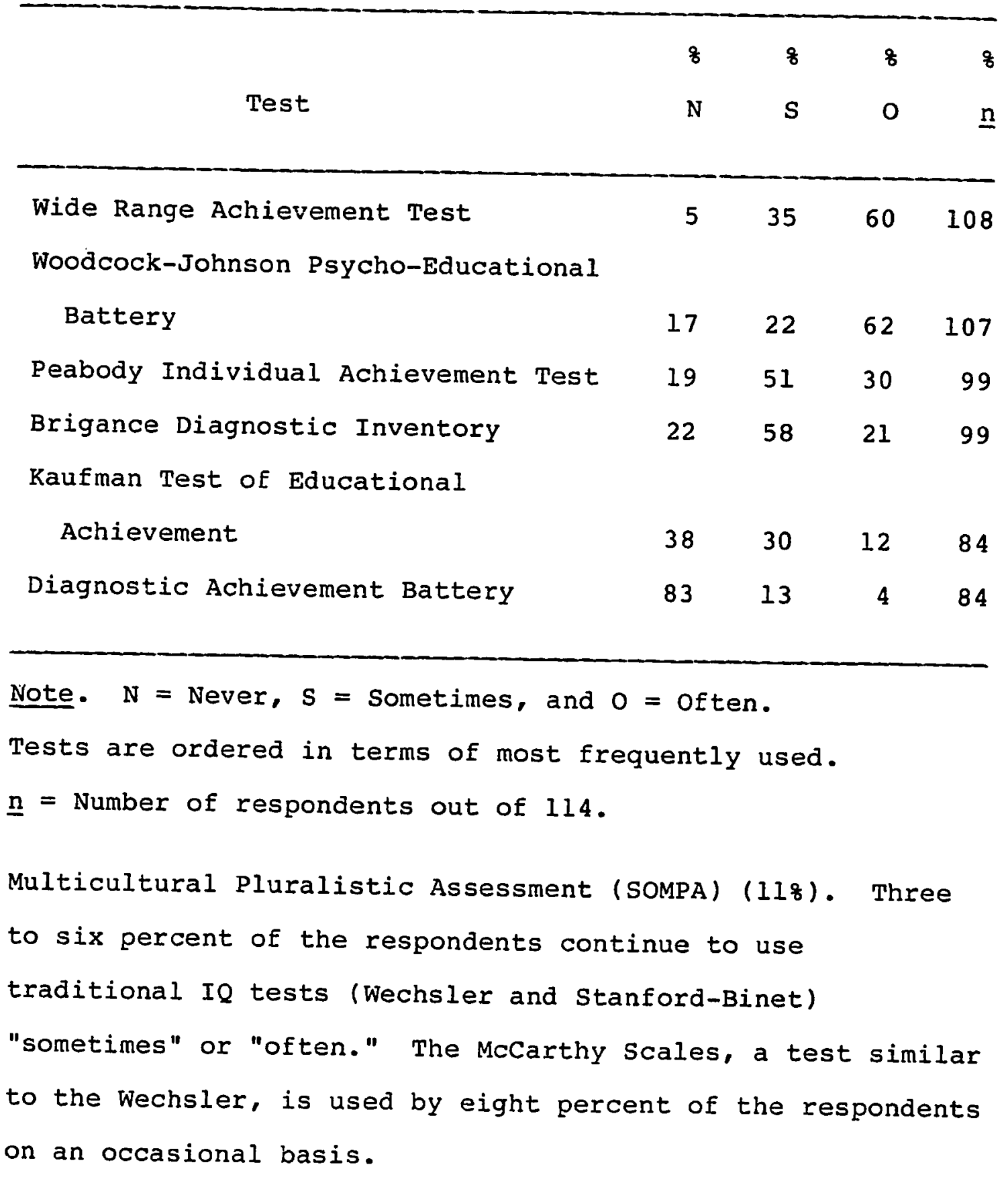


Table 5

Part Four: Percentages of Test Use and Frequency

for Intellectual Performance

\begin{tabular}{llllr}
\hline \multicolumn{1}{c}{ Test } & 8 & 8 & 8 & o \\
& N & S & 0 & $n$ \\
\hline Woodcock-Johnson Psycho-Educational & & & & \\
Battery & 77 & 21 & 2 & 87 \\
Learning Potential Assessment Device & 78 & 13 & 9 & 98 \\
System of Multicultural Pluralistic & & & & \\
Assessment (SompA) & 89 & 10 & 1 & 94 \\
Kaufman Assessment Battery & 89 & 6 & 4 & 94 \\
McCarthy Scales of Abilities & 93 & 8 & 0 & 93 \\
Test of Nonverbal Intelligence & 93 & 6 & 1 & 93 \\
Wechsler Intelligence Scale & 93 & 3 & 3 & 94 \\
Stanford-Binet Inteligence Scale & 97 & 3 & 0 & 93 \\
\hline
\end{tabular}

Note. $\mathrm{N}=$ Never, $\mathrm{S}=$ Sometimes, and $\mathrm{O}=$ often.

Tests are ordered in terms of most frequently used.

$\underline{n}=$ Number of respondents out of 114 .

Five tests are included in Table 6 . The three most frequently used instruments in the area of adaptive behavior are the Vineland Adaptive Behavior Scale (958); the AAMD Adaptive Behavior Scale (84\%), and the Scales of Independent Behavior (528). The Adaptive Behavior Inventory for 
Table 6

Part Four: Percentages of Test Use and Freguency

for Adaptive Behavior

\begin{tabular}{|c|c|c|c|c|}
\hline \multirow[b]{2}{*}{ Test } & 웅 & 8 & 8 & 8 \\
\hline & $\mathbf{N}$ & $\mathbf{s}$ & 0 & $\underline{\mathrm{n}}$ \\
\hline Vineland Adaptive Behavior Scale & 5 & 62 & 33 & 94 \\
\hline AAMD Adaptive Behavior Scale & 16 & 55 & 29 & 106 \\
\hline Scales of Independent Behavior & 49 & 36 & 16 & 84 \\
\hline \multicolumn{5}{|l|}{ Adaptive Behavior Inventory for } \\
\hline Chilaren & 60 & 34 & 6 & 83 \\
\hline Adaptive Behavior Evaluation Scale & 72 & 22 & 7 & 75 \\
\hline
\end{tabular}

Note. $\mathrm{N}=$ Never, $\mathrm{S}=$ Sometimes, and $\mathrm{O}=$ often.

Tests are ordered in terms of most frequently used.

$\underline{\mathrm{n}}=$ Number of respondents out of 114 .

Children and Rdaptive Behavior Evaluation Scale are used by less than $35 \%$ of the psychologists.

Seven instruments are included in Table 7 . The results show that, in the area of specific learning abilities and strategies, the three most frequently used tests are the Development Test of Visual-Motor Integration (898), the Motor-Free Test of Visual Perception (828), and the Auditory Discrimination Test (648). Bruininks-Oseretsky Test of Motor Proficiency is the least frequently used test. 
Table 7

Part Four: Percentages of Test Use and Frequency

for Specific Learning Abilities and Strategies

\begin{tabular}{|c|c|c|c|c|}
\hline Test & $\begin{array}{l}8 \\
\mathrm{~N}\end{array}$ & 8 & 0 & $\underline{8}$ \\
\hline \multicolumn{5}{|l|}{ Developmental Test of Visual-Motor } \\
\hline Integration & 10 & 33 & 56 & 96 \\
\hline Motor-Free Test of Visual Perception & 19 & 45 & 37 & 108 \\
\hline Auditory Discrimination Test & 36 & 46 & 18 & 89 \\
\hline $\begin{array}{l}\text { Detroit Tests of Learning Aptitude } \\
\text { Illinois Test of Psycholinguistic }\end{array}$ & 40 & 34 & 26 & 95 \\
\hline Abilities & 52 & 33 & 14 & 90 \\
\hline \multicolumn{5}{|l|}{ Goldman-Fristoe-Woodcock Auditory } \\
\hline Skills Test Battery & 66 & 26 & 9 & 82 \\
\hline \multicolumn{5}{|l|}{ Bruininks-Oseretsky Test of Motor } \\
\hline Proficiency & 83 & 17 & 0 & 81 \\
\hline
\end{tabular}

Note. $\mathrm{N}=$ Never, $\mathrm{S}=$ Sometimes, and $\mathrm{O}=$ often.

Tests are ordered in terms of most frequently used.

$\underline{\mathrm{n}}=$ Number of respondents out of 114 .

Twelve instruments are included in Table 8 . The three most frequently used measures in the area of classroom behavior are the Burk's Behavior Rating Scales (74\%), 
Table 8

Part Four: Percentages of Test Use and Frequency

for Classroom Behavior

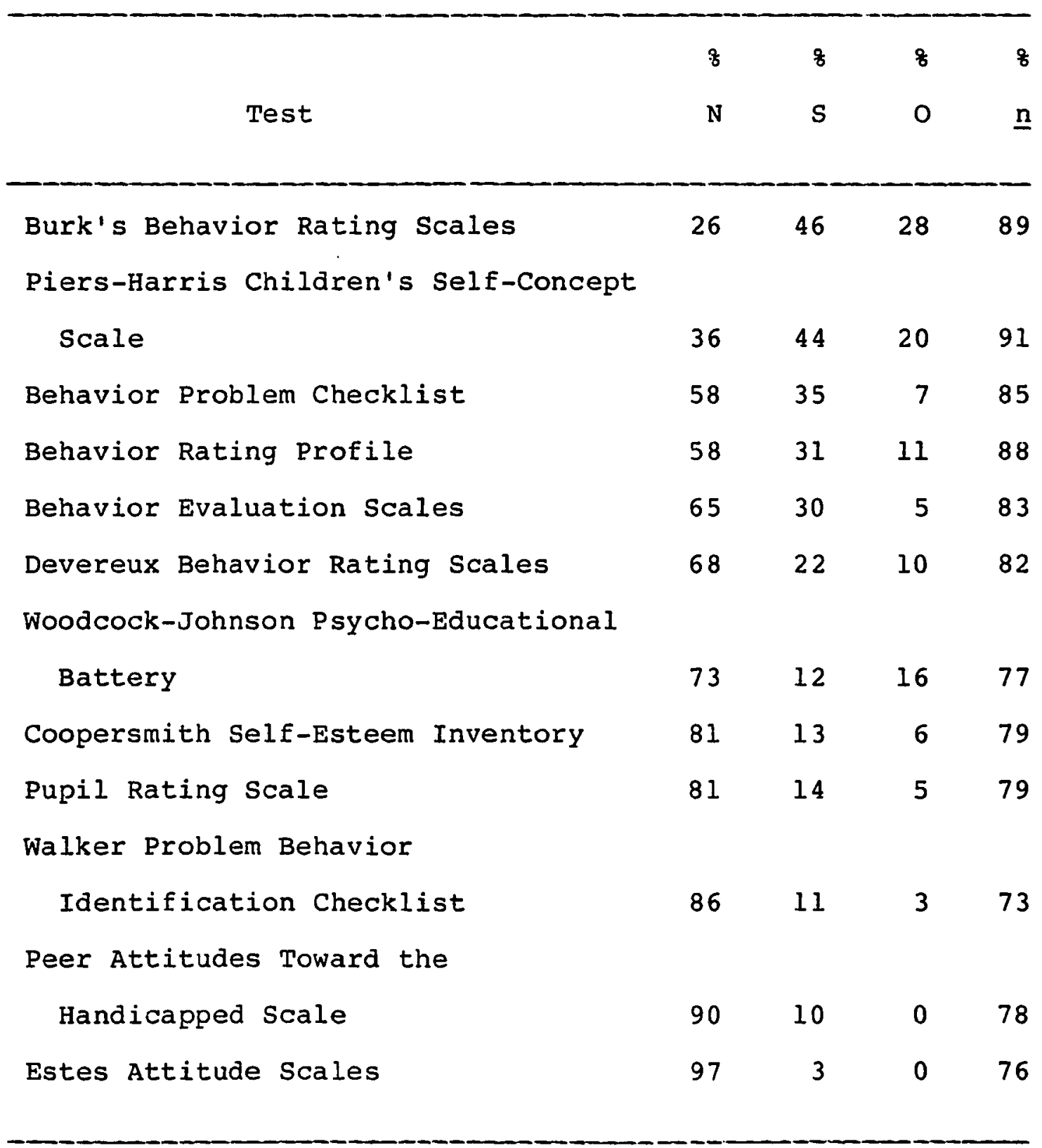

Note. $\mathbf{N}=$ Never, $\mathbf{S}=$ Sometimes, and $\mathrm{O}=$ often.

Tests are ordered in terms of most frequently used. $\underline{\mathrm{n}}=$ Number of respondents out of 114 . 
Piers-Harris Children's Self-Concept Scale (64\%), and the Behavior Problem Checklist (428). The Estes Attitude Scale is the least frequently used test.

Seven instruments are included in Table 9. The results show that, in the area of non-standardized measures, the three most frequently used sources of information are Cumulative Records (948), Teacher Interviews (928), and Observation of Classroom Behavior (908). Sentence Completion is the least frequently used test.

A total of twelve test instruments are listed in the categories of school achievement, intellectual performance, adaptive behavior, learning abilities and strategies, classroom behavior and non-standardized measures. Table 10 represents a list of the tests most frequently listed as "other" which were not provided on the survey, along with the number of subjects listing these tests. The three most frequently mentioned tests are in the areas of (I) intellectual performance and (2) learning abilities and strategies. They are the Raven's Progressive Matrices, Miller's Analogies Tests, and the Bender-Gestalt Test.

The last part of the survey asked psychologists to indicate the alternative methods and materials they have used to assess Black children for special education services that were not already listed in the survey. Table 11 presents the other methods and materials used to assess Black children. The three most prevalent methods and 
Table 9

Part Four: Percentages of Test Use and Frequency

for Non-standardized Measures

\begin{tabular}{llllr}
\multicolumn{1}{c}{ Test } & o & o & o & o \\
& N & S & 0 & $\underline{n}$ \\
\hline Cumulative Records & 1 & 5 & 94 & 108 \\
Teacher Interviews & 0 & 8 & 92 & 109 \\
Observation Classroom Behavior & 0 & 10 & 90 & 114 \\
Observation On-Campus Behavior & 0 & 12 & 88 & 106 \\
Student Interviews & 0 & 13 & 87 & 110 \\
Parent Interviews & 1 & 17 & 82 & 109 \\
Sentence Completion & 0 & 43 & 58 & 106 \\
\hline
\end{tabular}

Note. $\quad \mathrm{N}=$ Never, $\mathrm{S}=$ Sometimes, and $\mathrm{O}=$ often.

Tests are ordered in terms of most frequently used.

$\underline{\mathrm{n}}=$ Number of respondents out of 114 .

materials were Draw A Person (DAP), previous records school, medical, developmental, family), and Bender-Gestalt Test. Discussion

The majority of the subjects felt that the assessment process has become inadequate. They believed that Black children either received special education services when they did not need them or were denied services when they needed them. However, other studies and statistical reports 
Table 10

Part Four: List of "Other" Responses

Test

$\underline{\mathrm{n}}$

\section{School Achievement}

Key Math

13

Woodcock Reading Mastery

10

Test of Written Language (TOWL)

8

Intellectual Performance

Raven Progressive Matrices

Adaptive Behavior

Alpern-Boll

Specific Learning Abilities and Strategies

Visual Aural Digit Span (VADS)

Test of Visual Perception Skills (TVPS)

Bender Visual-Motor Gestalt

Classroom Behavior

Connors Parent Rating Scale

Connors Teacher Rating Scale

Non-standardized Tests

Drawings

Note. $\underline{n}=$ Number of respondents out of 114 listing test as other. 
Table 11

Part Four: List of "Other" Methods and Materials

Used to Assess Black Children

Test

$\underline{\text { n }}$

Drawing Tests (Draw A Person, House Tree

Person, Kinetic Family Drawing)

Previous Records (School, Medical,

Developmental, Family)

19

Bender Visual-Motor Gestalt Test

Raven's Progressive Matrices

Rorschach

Piagetian Tasks

Peabody Picture Vocabulary Test (PPVT)

Quick Neurological Screening Test

California Achievement Test (CAT)

Thematic Apperception Test (TAT)

Note. $\underline{n}=$ Number of respondents out of 1141 isting tests used to assess Black children other than those listed in the survey.

indicate that Blacks are overrepresented in the special education population. This suggests that there is a tendency to overadmit Black students. 
Many comments were given in response to Part Four, the assessment instruments section. Even though the majority of the public school psychologists had the freedom to choose which alternative assessments to use to diagnose a Black child for special education, they felt the instruments did not adequately diagnose Black children. This response suggests that psychologists do not like the tests that are legal, they are unaware of adequate testing materials, or they do not have access to adequate testing materials to diagnose Black children for special education. Some added that the current tests are inadequate becalise there is too much subjectivity on the part of the examiner and, under these circumstances, the accuracy of the decision is based on the expertise of the psychologist.

Some psychologists felt that the real need was not for training on the instruments but for reeducating the examiner. One subject stated, "It is the abuse of the test that gets the professional in trouble." Another stated, "It takes first the transcendence of racial prejudices and dealing with the examiner's own issues around their comfort level around Blacks." Those who did not feel the need for additional or specialized training commented on the need for better assessment materials. One subject reflected, "Will better training help a carpenter to drive nails without a hammer?" Even though the majority of the subjects believed the current identification of Black children is inadequate, 
a few were optimistic and believed that the identification process will improve.

Several psychologists commented on their questionnaire that they felt a ban of IQ testing only for Black children was unfair. San Francisco school districts have banned IQ testing of all children, regardless of race, creed, or color. Perhaps this is a decision that should be tried in other districts.

\section{Suggestions for Future Research}

From the information provided in this study, it is difficult to determine why particular tests are frequently used. Further research is needed to investigate influencing factors, such as the time allocated for test administration, content validity, examiner preference, time allotted for diagnosis of each child, and availability of tests. This study was not designed to determine the empirical adequacy of the tests that are used; however, research should be undertaken to determine the value of existing tests.

Some subjects reported that they were not the ones who administered the achievement tests (Table 4 ). These tests were selected and administered by other members of the Individuaiized Education Frogram team. However, the psychologists used the test results as part of their evaluations. Therefore, the results in this category reflect the choices made by persons other than the psychologists. Because other professionals participate in 
placement decisions in special education, future research should examine their opinions on the adequacy of the assessment of Black children. In future research, one-to-one interviews with a sample of psychologists should be conducted to obtain more in-depth information on the identification and alternative assessment process. 


\section{CHAPTER V}

\section{SUMMARY}

The goal of this study was to examine the identification process and the assessment instruments used to identify Black children for special education, as well as to determine the types of alternative tests used and their frequency of use. A questionnaire was designed to elicit answers to the following questions:

1. Are the alternative assessment instruments adequate in diagnosing Black children for special education?

2. What types of standardized tests are being used to diagnose Black children for special education?

3. Of the standardized tests being used for assessment, which are most frequently used?

4. What types of a].ternative assessment are being used by school psychologists to diagnose Black children for special education?

To obtain this information, 114 school psychologists employed in Alameảa, San Francisco, and Santa Clara counties were surveyed by mail. The results of this survey indicated that alternative assessment has had an adverse effect on the identification of Black children for special education placement. A majority of psychologists feel that Black students are being misplaced in special education; therefore, misplacement of minorities in special education continues to be a problem. School psychologists also 
believe that alternative assessment strategies inadequately diagnose Black children, deny special education to some Black children, and wrongly grant other Black children services when none are needed.

The information contained in this survey provides insight into the psychologists' feelings about the ban on IQ testing and the use of alternative forms of assessment. This survey enables special education professionals and psychoiogists to know the types of alternative assessment that are used to replace IQ testing. Ranking the tests by frequency of use may encourage psychologists and other professionals to experiment with unfamiliar materials, thus broadening their professional expertise. The results also point out the concern for more effective ways to identify the special education needs of Black children. Implications for the Future

The decision made by Judge Peckham to ban IQ testing of all Black children may not be upheld for several reasons: psychologists are not satisfied with the instruments they have to assess Black students for special education; some parents do not feel their children are being properly assessed; and court cases like Crawford v. Honig may continue to crowd the court dockets for years to come. The ban on IQ testing is a step in the direction of more adequate assessment; however, more research is needed to determine the means of alternate assessment. It is the 
writer's opinion that psychologists who hold fast to IQ testing are not sensitive to the cultural biases in the IQ instruments or are unable to support alternative assessment as a better means of identifying Black children for special education. Hence, it is easy to see why psychologists are unable to justify banning IQ tests. Another issue is the banning of IQ testing for only Black children. Psychologists and parents may be tempted to misreport the racial status of children so they can be given the IQ test. The question of interracial children and whether or not the ban applies to them will also require study. Unsolved court cases and confusion over the choice of adequate alternative assessment strategies may result in children being misclassified. 
REFERENCES 
Baca, L. M., \& Cervantes, H. T. (1984). The bilingual special education interface. Ohio: Merrill.

California Public School Directory. (1987). Sacramento, CA: Bureau of Publications, State Dept. of Educ.

Campbell, P. (1988, March/April). Larry P. implementation: SDE calls for immediate purging of IQ references. California Association of School Psychologists (CASP TOday), pp. 1, 40.

Dent, H. E. (1985, September). The Larry P. compliance program. Paper presented at workshop on Larry $P$. decision, Berkeley, CA.

Gentry, R. (1983). Assessing problems and needs in educating minority handicapped children. Jackson, MI: Jackson State University. (ERIC Document Reproduction Service No. ED 234565 ).

Lambert, N. M., Gleason, W. P., \& Wilcox, M. R. (1972). Assessment manual for the diagnosis of EMR pupils. Berkeley University of California.

Lewis, R. B., \& Doorlag, D. H. (1983). Teaching special students in the mainstream. Ohio: Merrill. Lopez, R. (1988, August). What is an alternative assessment? California Association of School Psychologists Today (CASP Today), p. 22. McLoughlin, J. A., \& Lewis, R. B. (1986). Assessing special students. Ohio: Merrill. 
Olion, L., \& Gillis-Olion, M. (1984). Improving the assessment of black students. Education Digest, 49 , 26-29.

Porter, K. (1987, September/October). Advisory group at work... Larry P. ... ...R ...S and ...T. California Association of School Psychologists Today (CASP Today), pp. 1,37 .

Prasse, D. P., \& Reschly, D. J. (1986). Larry P.: A case of segregation, testing, or program efficacy? Exceptional Children, $\underline{52}(4), 333-345$.

Ramage, J., Logan, R., \& Thomas, B. (1988, May). Policy, assessment models proposed: Task force aims to end overrepresentation. Special Edge, $\underline{2}(8), 2$.

Rose, E., \& Huefner, D. S. (1984). Cultural bias in special education assessment and placement. (ERIC Documentation Reproduction Service No. ED 244335 ).

Sattler, J. M. (1988, August). Larry P.: Challenge to judgment filed in federal court. California Association of School Psychologists Today (CASP Today), pp. 1, 20 . Staff. (1986, November). Judge Peckham decides: Extend the ban on use of IQ tests with Black children. California Association of School Psychologists Today (CASP Today), pp. 1,32 .

Staff. (1987, January). Reaction to Larry P. judgment. California Association of School Psychologists Today (CASP Today), pp. 1, 32 . 
Taylor, R. L. (1989). Assessment of exceptional students: Educational \& psychological procedures. NJ: Prentice Hall.

Winget, P. (1988a, May). Larry P. judgment changes psychologists' roles and practices. Special Edge, $2(8)$, 4,9 .

Winget, P. (1988b, May). State, field work to end cultural bias. Special Edge, $2(8), 1,10$. 
APPENDICES 
APPENDIX A 
Dear School Psychologist,

Because the California State Department of Education was ordered by a Federal Court to discontinue the use of culturally biased IQ tests for the assessment and special education placement of Black students, there is a need to identify suitable alternative methods for assessing their educational needs. Thus, the objective of this questionnaire is to obtain the school psychologists' perspective on minority assessment and to survey the types of assessments being used to identify Black students for special education screening and placement. Please assist me by filling out the attached questionnaire and returning it in the self-addressed stamped envelope no later than Friday, Feb. 28, 1989. If you would like a sum mary of the results of this survey, please fill out the information section in the questionnaire. This section is separated from the questionnaire to assure anonymity. The summary will be returned to you at the completion of the study.

Your participation in this study is strictly voluntary. Also, your name, if you choose to disclose it, will remain anonymous and will only be disclosed if required by law. The resulting study will include only statistical data. No names will be mentioned. Completing this questionnaire poses no known risks.

If you have any questions about this study, I would be happy to talk with you. I can be reached at (408) 924-3686. I hope you will find the time to help us identify the alternative methods being used to assess Black students' educational needs so they can be appropriately assessed and identifed for special services.

Thank you for your cooperation,

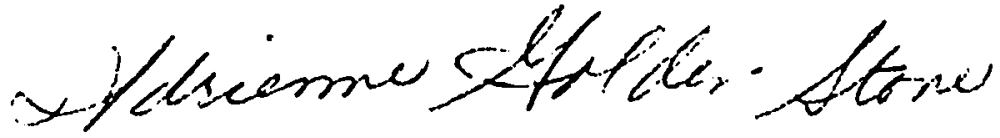

Adrienne Golden-Stone

LH Master's Degree Candidate 
PART OINE

The following information is used for demographic purposes only:

Please check one

Institution: — Preschool — Public

_ Elementary _- Private

- Secondary

$\mathrm{K}-12$

Special Education Population:

Learning Handicapped

- SDC - RSP

- EMR SED

- Severely Handicapped

- Other

Current Position

Years in Position

Have you completed any surveys on this issue before?

If so, when 
If you would like to recelve a summary of the results, please fill in the return address information below:

District/School

(please print)

Name

Address

City/Zip 
Directions: Please indicate your feelings about each item PART TWO by circling youi response.

\section{IDENTIFICATION PROCESS}

1. Because psychologists no longer use IQ tests, the diagnosis of Black children using other means has become:

more than adequate adequate inadequate

2. Because alternative testing. must be used to identify Black children for Special Education, some may be denied access to its services.

strongly agree mildly agree neither agree or disagree mildly disagree strongly disagree

3. Because alternative testing must be used to identify Black children for Special Education, some may be misplaced and receive services when none are needed.

strongly agree mildly agree neither agree or disagree

PART THREE

mildly disagree strongly disagree

ASSESSMENT INSTRUMENTS

4. Does your district mandate which tests must be used to assess Black students for Special Education (iearning handicapped) place ment?

$$
\text { Orten Sometimes Never }
$$

5. Do you feel that the current tests available are adequate for the assessment of Black children?

Yes No

6. Do you feel additional or specialized training is needed to assess Black children for Sperial Etucation?

Yes No 
PART FOUR

Listed below are some of the standardized tests currently used to assess children for Special Education. In ficate the ones you use for Black children and the frequency of use for each test by checking the proper column:

$N=$ never, $S$ - sometimes, 0 - often

School Achleuement

Brigance Diagnostic Inventory

Diagnostic Achievement Battery

Kaufman Test of Educ. Achievement

Peabody Individual Achievement Test

Wide Range Achievement Test

Woodcock-Johnson Psycho-Educ. Battery

Other
N $\quad \mathrm{S} \quad \mathrm{O}$

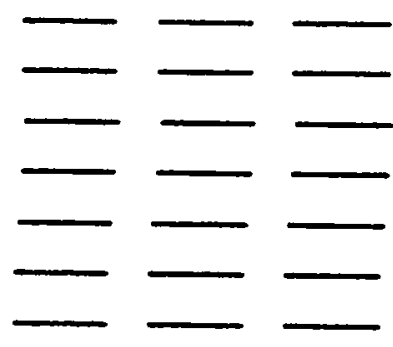

\section{Intellectual Periormance}

Kaufman Assessment Battery

Learning Potential Assessment Device

McCarthy Scales of Abilities

Stanford-Binet Intelligence Scale

System of Multicultural Pluralistic

Assess ment (SOMPA)

Test of Nonverbal Intelligence

Wechsler Intelligence Scale

Woodcock-Johnson Psycho-Educ. Battery

Other

\section{Adoptive Behavior}

AAMD Adaptive Behavior Scale Adaptive Behavior Inventory for Children Scales of Independent Behavior Vineland Adaptive Behavior Scales Adaptive Behavior Evaluation Scale Other

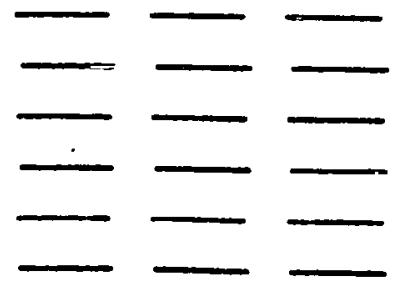


Indicate the ones you use for Black children and the frequency of use for each test by checking the proper column:

N - never, S - sometimes, 0 - often

Specific Learning abllities and Strotegies

Auditory Discrimination Test

Bruininks-Oseresky Test of Motor Prof.

Detroit Tests of Learning Aptitude

Developmental Test of Visual-Motor

Integration

Goldman-Fristoe-Woodcock Auditory

Skills Test Battery

Illinois Test of Psycholinguistic

Abilities

Motor-Free Test of Visual Perception

Other

\section{Classroom Behaulor}

Behavior Rating Profile

Behavior Evaluation Scale

Behavior Problem Checklist

Burk's Behavior Rating Scales

Coopersmith Self-Esteem Inventories

Devereur Behavior Rating Scales

Estes Attitude Scales

Peer Attitudes Toward the

Handicapped Scale

Piers-Harris Children's Self-concept

Sca'?

Pupil Rating Scale

Walker Problem Behavior

Identification Checklist

Woodcock-Johnson Psycho-Educ. Battery

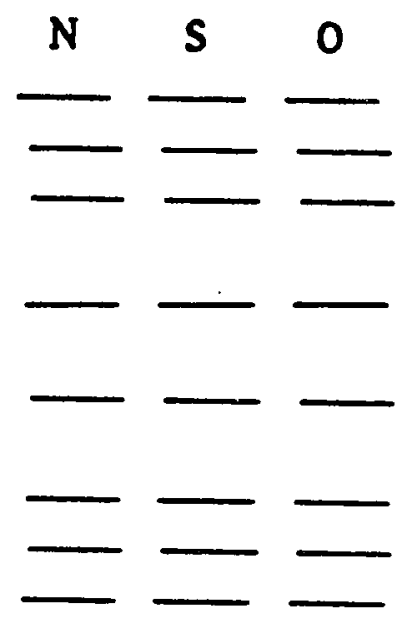

Other
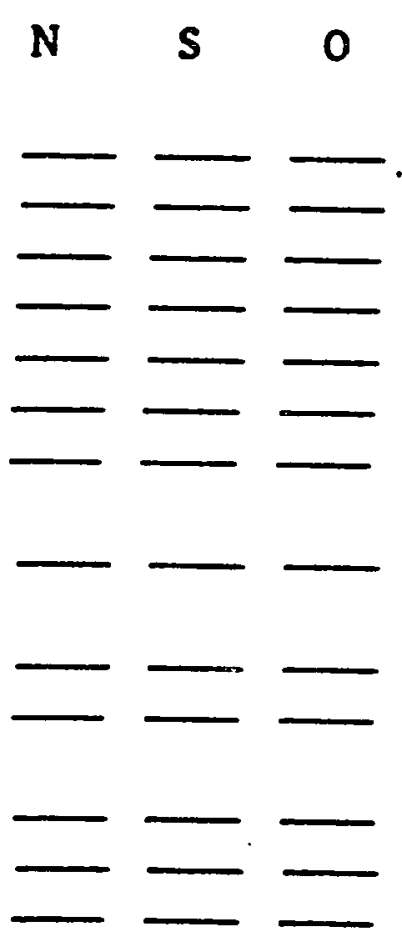
Indicate the ones you use for Black children and the frequency of use for each test by checking the proper column:

$\mathrm{N}=$ never, $\mathrm{S}$ - sometimes, $\mathrm{O}=$ Orten

Non-Stonderdized Tests

Interviews

$\mathbf{N} \mathbf{S} \mathbf{0}$

Parent

Student

Teacher

Cumulative Records

Observation

On-campus behavior

Classroom behavior

Sentence Completion

Other

What other methods and materials have you used 10 assess Black children for special education services that have not already been listed? 
APPENDIX B 


\section{PLEASE NOTE:}

Copyrighted materials in this document have not been filmed at the request of the author. They are avallable for consultation. however. in the author's university library.

These consist of pages:

$60-86$ 